УДК $343.222: 614.25 ; 343.618$

CERIF: S149

\title{
Др Јелена Ђуришић
}

\section{СПОРНА ПИТАЮА У ВЕЗИ СА КРИВИЧНИМ ДЈЕЛОМ НЕСАВЈЕСНО ПРУЖАЬЕ ЉЕКАРСКЕ ПОМОЋИ}

У раду су разматрана одређена спорна питања у вези са кривичним дјелом несавјесно пружање ьекарске помоћи међу којима се посебно истичу сљедећа: прво питање се односи на тумачење појмова пружања љекарске помоћи и лијечења у контексту анализираног кривичног дјела, а у складу са тим и назива кривичног дјела несавјесно пружање ьекарске помоћи док се као треће отвара питање категорија лица која могу бити учиниочи тог кривичног дјела будући да је из законског описа дјела изостављена категорија здравствених сарадника као лица која би, осим здравствених радника, могла учинити то кривично дјело.

У раду се истиче значај поштовања протокола о лијечењу и значај оснивања националних система за пријављивање и праћење стручних грешака у области здравствене дјелатности. Строго поштовање протокола о лијечењу и уредно вођење медицинске документащије има вишеструки значај будући да она представља најсигурнији вид заштите и здравственог радника, односно здравственог сарадника и лица које остварује право на здравствену заштиту.

Кључне ријечи: Кривично дјело несавјесно пружање векарске помоћи. - Узрочна веза. - Тумачење појма лијечења. - Здравствени сарадницุи.

\section{1. УВОДНА РАЗМАТРАЬА}

Право на здравље као основно људско право предвиђено је бројним међународноправним документима. На националном нивоу, то право је гарантовано уставним одредбама, а заштита права на здравље и здравствену заштиту пружа се бројним гранама пра-

* Ауторка је асистенткиња на Факултету правних наука Универзитета Доња Горица у Подгорици, jelena.popovic@udg.edu.me. 
ва. Иако здравље човјека представља један од важнијих заштитних објеката, фрагментарни карактер кривичног права овдје посебно долази до изражаја будући да се кривичноправна заштита пружа само у случајевима озбиљног угрожавања, односно повреде здравља лица. У новије вријеме све актуелнија постају и питања из области биомедицине, гдје се такође, у одређеним случајевима, као оправдана показује и кривичноправна интервенција. ${ }^{1}$

Термин стручна љекарска грешка први пут се у стручној литератури помиње у XIX вијеку иако је настао и много раније. Тако се као прва позната дефиниција појма стручне љекарске грешке јавља дефиниција њемачког љекара Фирхова (Virchow), који је стручну љекарску грешку дефинисао као „кршење општепризнатих правила вјештине лијечења, услијед одсуства потребне пажње и опрезности“. У контексту савремене медицине и права, под појмом стручне љекарске грешке подразумијева се свако поступање које је contra legem artis. ${ }^{2}$

Кривично дјело несавјесно пружање љекарске помоћи данас се све чешће процесуира. За разлику од развијенијих земаља свијета у којима је покретање поступака против здравствених радника давно постало пракса, народи нашег поднебља су се услијед менталитетске матрице, али и недовољне информисаности, само у изузетно ријетким случајевима упуштали у дуготрајне судске поступке. ${ }^{3}$

На самом почетку разматрања те изузетно важне тематике важно је нагласити да стручна љекарска грешка сама по себи не повлачи одмах ни кривичну ни грађанску одговорност већ је неопходно да је због несавјесно пружене љекарске помоћи наступило погоршање здравственог стања лица. ${ }^{4}$ Доказивање постојања узрочне везе између несавјесно пружене љекарске помоћи и погоршања здравственог стања пацијента у пракси је по правилу веома сложено будући да је у питању утврђивање односа између постојећег и непостојећег. У том контексту посебно комплексно питање може се јавити у случају

1 Зоран Стојановић, Коментар Кривичног законика, Подгорица 2010, 604.

2 Милан Почуча, Небојша Шаркић, Наташа Мрвић Петровић, „Лекарска грешка као разлог правне одговорности лекара и здравствених установа“, Војносанитетски преглед 2/2013, Београд, 208.

3 Љекарска комора Србије први пут је 2011. године трајно одузела лиценцу љекару Н. 3. након правноснажне пресуде Апелационог суда у Крагујевцу за тешко дјело против здравља људи, којом је осуђен на осмомјесечну казну затвора због несавјесног лијечења четворогодишње дјевојчице, која је преминула. Суђење је трајало 12 година. У Црној Гори тренутно су у току кривични поступци против петнаестак љекара по тужби пет породица за кривично дјело несавјесно пружање љекарске помоћи, чији су чланови преминули у току лијечења или убрзо након отпуштања.

4 Mario Pompili, Stephen Ferracuti, ,Suicide and some of its legal problems with particular reference to the shizophrenia patient", Crimen 1/2011, 34-36. 
када се нечињење љекара сматра узроком погоршања здравственог стања лица, што заправо представља и најсуптилније практично питање у области медицинског права. ${ }^{5}$ С обзиром на то да љекар према пацијенту има положај гаранта те да је дужан да медицинским мјерама штити његов живот и здравље, у случају када се његово здравствено стање значајно погорша, одговорности љекара могу се приписати настале нежељене посљедице само када се утврди да је предузимањем потребних мјера било могуће спријечити погоршање здравственог стања односно смрт. ${ }^{6}$ Дакле, не утврђује се стварна већ хипотетичка узрочна веза, при чему се полази од претпоставке да је лице о чијем пропуштању је ријеч имало реалну могућност да благовременим и сврсисходним чињењем спријечи или умањи штету која је пријетила те да се то од учиниоца дјела оправдано могло очекивати. ${ }^{7}$ У том смислу, интересантно је да у случају утврђивања постојања кривице љекара њемачки судови захтијевају да узрочна веза између љекарске грешке и погоршања здравственог стања односно смрти пацијента буде сигурнија него када је у питању утврђивање одговорности у грађанском праву, тражећи „степен вјероватноће који се граничи са сигурношћу“. Тако у бројним новијим судским одлукама питање узрочности није довођено у везу искључиво са спасавањем живота, као што је то раније чињено, већ са његовим продужењем па се, сходно томе, медицинским вјештацима за вријеме вођења кривичног поступка све чешће упућује питање да ли би пацијент, да је исправно лијечен, преживио тренутак смрти са вјероватноћом која се граничи са сигурношћу? ${ }^{8}$

\section{2. НОРМАТИВНА КОНСТРУКЦИЈА КРИВИЧНОГ ДЈЕЛА НЕСАВЈЕСНО ПРУЖАЬЕ ЉЕКАРСКЕ ПОМОЋИ}

Кривично дјело несавјесно пружање љекарске помоћи регулисано је чл. 251 Кривичног законика Србије ${ }^{9}$ и чл. 290 Кривичног законика Црне Горе ${ }^{10}$. Кривично дјело несавјесно пружање љекарске помоћи има два основна облика која се разликују према томе ко

5 Јаков Радишић, „Одговорност љекара због смрти пацијента изазване нехатним нечињењем - поглед у њемачку правну теорију и судску праксу“, Анали $\Pi \Phi Б 1 / 2012,20$.

6 Ненад Ђурђевић, „Кривична одговорност лекара у случају самоубиства пацијента“", Југословенска ревија за криминологију и кривично право 1-2/1997, 250;

7 Ј. Радишић (2012), 20.

8 Ibid.

9 Кривични законик, Службени гласник $P C$, бр. 85/05, 88/05, 107/05, 72/09, $111 / 09,121 / 12,104 / 13$ и 108/14.

10 Кривични законик, Службени лист ЦГ, бр. 70/03, 13/04, 47/06, 40/08, 25/10, 32/11, 64/11 и 40/13. 
може бити извршилац кривичног дјела па, сходно законским одредбама, извршилац првог основног облика може бити љекар, док се као извршилац другог основног облика јавља други здравствени радник који у пружању медицинске помоћи или његе односно у вршењу друге здравствене дјелатности очигледно несавјесно поступа и тиме узрокује погоршање здравственог стања лица.

Радња извршења првог основног облика кривичног дјела огледа се у четири алтернативно постављене радње извршења, које морају бити предузете у току лијечења односно пружања љекарске помоћи. У пракси је могуће да љекар у току лијечења, односно пружања љекарске помоћи изврши више алтернативно постављених радњи извршења дјела, при чему то неће имати утицаја на квалификацију кривичног дјела.

Као прва алтернативна радња извршења првог основног облика кривичног дјела несавјесно пружање љекарске помоћи наводи се примјена очигледно неподобног средства лијечења. У том смислу средствима лијечења треба сматрати медицинска средства и лијекове. Средствима лијечења односно медицинским средствима, сходно одредбама Закона о медицинским средствима ${ }^{11}$ и Закона о лековима и медицинским средствима ${ }^{22}$, сматрају се инструменти, апарати, уређаји и производи који се примјењују на људима у складу са намјеном коју им је одредио произвођач, а који своје основно дјеловање не постиже на основу фармаколошких, имунолошких и метаболичких особина. Медицинска средства могу се користити самостално или у комбинацији, у сљедећим случајевима: утврђивање дијагнозе, превенција, праћење лијечења или ублажавања болести; праћење лијечења или ублажавања повреда или инвалидитета; испитивање, замјена или модификација анатомских или физиолошких функција и контрола зачећа (чл. 2). ${ }^{13}$ У свакој поменутој намијени медицинско средство може бити потпомогнуто супстанцама које испољавају фармаколошке, имунолошке или метаболичке активности. Употреба медицинског средства носи и одређене ризи-

11 Закон о медицинским средствима, Службени лист ЦГ, бр. 79/04 и 53/09.

12 Закон о лековима и медицинским средствима, Службени гласник $Р C$, бр. $30 / 2010$.

13 Медицинским средством сматра се и оно средство које не испуњава своју основу намијену у или на људском организму фармаколошком, имунолошком или метаболичком активношћу, али може у својој намјени бити потпомогнуто супстанцама у свом саставу које испољавају исту такву активност. У општа медицинска средства спадају и помоћна средства која по дефиницији нису медицинска средства, а која означавају производ који је намијењен да у комбинацији са медицинским средством омогући његову употребу, затим медицинско средство произведено по наруџби за одређеног пацијента, израђено у складу са писаним упутством одговарајућег стручњака, који имају посебне конструкционе карактеристике, као и медицинско средство намијењено клиничком испитивању. 
ке који се могу испољити као нежељено, али и озбиљно нежељено дејство медицинског средста. ${ }^{14}$ Стога је, у контексту анализиране проблематике, важно приближити односно разјаснити значење појма „нежељеног дејства медицинског средства“ и „озбиљно нежељеног дејства медицинског средства“. Тако под појмом нежељеног дејства медицинског средства треба схватати свако штетно, односно неодговарајуће дејство медицинског средства, али и свако одступање од карактеристика и/или дјеловања медицинског средства које није у складу са ознаком и упутством за примјену, а које може, посредно или непосредно, изазвати смрт или угрозити здравствено стање пацијента, односно корисника и безбједност других лица. За разлику од нежељеног дејства медицинског средства озбиљно нежељено дејство медицинског средства подразумијева свако штетно, односно неодговарајуће дејство медицинског средства, свако одступање од карактеристика и/или дјеловања медицинског средства које није у складу са ознаком и упутством за примјену, а које је, посредно или непосредно, изазвало смрт, непосредну животну угроженост, болничко лијечење, односно продужетак болничког лијечења пацијента, ако за тим није било потребе прије употребе медицинског средства, као и корисника и других лица (чл. 5). ${ }^{15}$

У случају да је наступило нежељено или озбиљно нежељено дејство медицинског средства које је за посљедицу имало нарушавање здравља лица, одговорност љекара ће бити искључена уколико је његово поступање било у складу да медицинским стандардима и правилима лијечења која је требало спровести у конкретном случају, што је у складу са начелним правилом да је здравствена установа дужна да примјењује само научно провјерене и доказане медицинске методе и поступке, као и стручно провјерене, традиционалне и алтернативне методе лијечења, које нијесу штетне по здравље лица. Сходно законским одредбама, захтијева се да здравствени радници обављају здравствену дјелатност у складу са важећом доктрином и кодексом професионалне етике па у том смислу за свој рад преузимају стручну, етичку, кривичну и материјалну одговорност (чл. 169). ${ }^{16}$

14 Према степену ризика за корисника, медицинска средства се дијеле на средства са ниским, вишим, високим и највишим степеном ризика, а према природи производа, повезаности са изворима енергије и другим карактеристикама на: неинвазивна, инвазивна и активна. У Србији и Црној Гори у промету могу бити само медицинска средства која испуњавају законима прописане опште и посебне услове.

15 Закон о здравственој заштити - 333 ЦГ, Службени лист ЦГ, бр. 39/04, $14 / 10,73 / 10$ и $40 / 11$.

16 Закон о здравственој заштити - 333 РС, Службени гласник $P C$, бр. 107/15, 72/09 - др. законом, 88/2010, 99/2010, 57/2011, 119/2012, 45/2013 - др. законом, 93/2014, 96/2015 i 106/2015. 
Како лијечење у смислу тог кривичног дјела обухвата постављање дијагнозе, као и одређивање и примјену терапије, и постављање погрешне дијагнозе која за посљедицу има примјену неподобног средства улази у појам овог облика радње извршења кривичног дјела. ${ }^{17}$ Узимајући у обзир да се употреба неподобног средства лијечења са аспекта кривичног права и криминалне политике донекле може толерисати, захтијева се да употреба односно примјена неподобног средства мора бити очигледно неподобна, односно ријеч је о степеновању неподобности, то јест мора се радити о високом степену неподобности. Дакле, „очигледно“ мора представљати упадљиву стручну грешку којом се грубо крше правила медицинске струке и науке. ${ }^{18}$

Као и у случају примјене очигледно неподобног медицинског средства, и примјена очигледно неподобног начина лијечења подразумијева све оно што у дјелатности љекара очигледно одступа од важећих, општеприхваћених принципа медицинске науке и праксе. ${ }^{19}$ Важно је истаћи да је овдје заправо ријеч о алтернативној радњи извршења кривичног дјела која је веома слична примјени очигледно неподобног средства лијечења па из тог разлога средство и начин у разматраном контексту некада није ни могуће изоловано посматрати. Ипак, кључну разлику између медицинског средства и начина лијечења треба тражити у схватању да је начин лијечења заправо шири појам који, осим употребе медицинског средства, обухвата и друге поступке и третмане, који се могу спроводити и без примјене или давања лицу одређених средстава. ${ }^{20}$ У том смислу, као и у првој алтернативно постављеној радњи извршења, и овдје мора постојати висок степен неподобности начина лијечења. Очигледна неподобност начина лијечења и у овом случају мора представљати упадљиву стручну грешку љекара којом се грубо крше правила струке и науке. ${ }^{21}$

У теорији и науци кривичног права постоји став да и пропуштање предузимања превентивних мјера такође може представљати радњу извршења тог облика кривичног дјела. Иако је разумљиво да се такве мјере не могу предузимати против воље пацијента, да би поступање љекара било савјесно, он треба да се увјери да пацијент схвата значај и карактер посљедица које потенцијално могу наступити по његово здравље. ${ }^{22}$

17 Зоран Стојановић, Коментар Кривичног законика, Београд 2012, 727.

18 Ibid.

19 Слободан Савић, „Кривична дела у вези са обављањем лекарске делатности“, Научни часопис ургентне медищине - Хало 94 2/2010, 57.

20 3. Стојановић (2010), 607.

21 Ibid.

22 Бора Чејовић, Кривично право у судској пракси, Посебни део, Крагујевац 2008, 627 . 
Трећа алтернативна радња извршења првог основног облика тог кривичног дјела јесте непримјењивање одговарајућих хигијенских мјера, што заправо у пракси најчешће подразумијева пропуштање предузимања одговарајућих хигијенских мјера. Медицинска струка у том смислу поставља одређене стандарде сходно којима хигијенске мјере могу бити општег и посебног карактера. ${ }^{23}$ Исто тако, овдје се има у виду и примјена одређених мјера, али не само мјера које је требало предузети већ и начина на који је то било неопходно учинити. Непримјењивање одговарајућих хигијенских мјера може се јавити и као радња извршења тог дјела у случају када се као учинилац јавља било који здравствени радник који при пружању медицинске помоћи или његе или при вршењу друге здравствене дјелатности очигледно несавјесно поступа и тиме проузрокује погоршање здравственог стања неког лица. ${ }^{24}$

Четврта алтернативно постављена радња извршења првог основног облика дјела огледа се у уопште очигледно несавјесном поступању којим се проузрокује погоршање здравственог стања неког лица. У том контексту, очигледно несавјесно поступање требало би схватити на начин као и у осталим алтернативним облицима радње извршења овог дјела, али је уобичајено да се под овим обликом радње извршења подразумијевају два случаја: непримјењивање очигледно подобног средства или начина лијечења, или се пак може радити и о општој несавјесности која није специфична само за поступак лијечења. ${ }^{25}$ У том смислу и овдје треба захтијевати виши степен несавјесности тим прије што се појмом „опште несавјесности“ могу обухватити врло хетерогене ситуације, па и атипични случајеви у којима је могућност настанка грешке вјероватнија. ${ }^{26}$

Други основни облик кривичног дјела несавјесно пружање љекарске помоћи може извршити други здравствени радник у пружању медицинске помоћи или његе или у вршењу друге здравствене дјелатности. С обзиром на то да извршилац другог основног облика не може бити љекар већ други здравстевени радник односно лице које обавља одређене послове у области пружања медицинске помоћи или друге здравствене дјелатности, радња извршења кривичног дјела прилагођена је управо томе, то јест није ријеч о лијечењу већ о пружању медицинске помоћи или његе или вршењу друге здравствене дјелатности, при чему је за постојање радње извршења дјела потребно да извршилац при обављању тих дјелатности поступа очиглед-

23 3. Стојановић (2012), 728.

24 С. Савић, 57.

25 3. Стојановић (2010), 608.

26 Зоран Стојановић, Наташа Делић, Кривично право, Посебни део, Београд 2015, 186. 
но несавјесно. Као и у случају првог основног облика дјела, ни овдје није довољно постојање блажих облика несавјесности. ${ }^{27}$ Обим радњи које у свом раду спроводе категорије лица које према тексту законика могу учинити други основни облик дјела, односно други здравствени радници најчешће чини спровођење терапије према упутству љекара, давање љекова, превијање, обављање физикалне терапије, давање инјекција, вршење разних облика његе и осталих послова у вези са пружањем помоћи. ${ }^{28}$ У друге здравствене дјелатности сврставају се и поступци као што су: архивирање медицинске документације, узимање крви или другог биолошког материјала, обављање лабораторијских анализа и снимања, стерилизација инструмената, асистенција приликом различитих врста хируршких захвата и др.

Кривично дјело несавјесно пружање љекарске помоћи из ст. 1 и 2 може бити извршено само са евентуалним умишљајем, док уколико је дјело извршено из нехата, што може обухватити и свјесни и несвјесни нехат, постоји лакши облик тог кривичног дјела из ст. 3. Законодавац, осим два основна и лакшег облика кривичног дјела несавјесног пружања љекарске помоћи, познаје и квалификоване облике у случају наступања тешких посљедица регулисаних чл. 302 Кривичног законика (тешка дјела против здравља људи).

\section{3. ПРОБЛЕМИ КОЈИ СЕ ЈАВЉАЈУ У ПРИМЈЕНИ КРИВИЧНОГ ДЈЕЛА НЕСАВЈЕСНО ПРУЖАЬЕ ЉЕКАРСКЕ ПОМОЋИ}

Према недавно објављеним резултатима истаживања спроведеног на Универзитету Џон Хопкинс (Johns Hopkins) у Сједињеним Америчким Државама услијед стручне грешке здравствног радника сваке године у просијеку живот изгуби око 250.000 пацијената, што се, према ријечима аутора студије М. Мекарије (М. Мекагіа), може сматрати трећим по реду узроком смрти у тој земљи, а вјероватно и у свијету. Ипак, истраживачи упозоравају да медицинске грешке не би требало да буду синоним за лоше љекаре, али да указују на заиста озбиљне и дубоке системске проблеме, укључујући лошу координацију, недовољне административне капацитете, подијељене мреже осигурања, недостатак или недовољно коришћење заштитних мрежа и протокола лијечења. ${ }^{29}$ У том смислу, аутор студије посебно

27 Ibid.

28 Даница Степић, „Кривична одговорност лекара за несавесно пружање лекарске помоћи - упоредноправна анализа кривичних законодавстава неких земаља Југоисточне Европе“, Страни правни живот 2/2009, Београд, 201.

29 https://www.jhu.edu/, http://www.glasamerike.net/a/medical-errors/3340214.html, асп. 21. мај 2016. 
наглашава да заправо нико нема тачне и потпуне податке о томе колико је лица преминуло услијед начињене стручне медицинске грешке с обзиром на то да Свјетска здравствена организација, као ни центри за праћење болести не користе код за медицинске грешке, попут кодова који се користе на рачунима, како би се установили водећи узроци смрти. Управо због недостатка кода за медицинске грешке, Мекарија истиче да се проблему проучавања медицинске грешке не може озбиљније приступити, наглашавајући да је то једина област медицине која није документована. ${ }^{30}$

Слично истраживање вршено је осамдесетих година на Институту „Роберт Кох“ (Robert Koh) у Њемачкој када су истраживачи дошли до податка да се у Њемачкој годишње у просјеку поднесе 40.000 пријава због начињене стручне љекарске грешке. ${ }^{31}$ У Њемачкој се та врста статистике води од 1979. године, а од 2006. године на националном нивоу евиденција се води помоћу Система извјештавања о љекарским грешкама (Medical Error Reporting System - MERS). Taj систем је изузетно значајан и подаци до којих се тим путем дође користе се за идентификацију стручних грешака, развијање стратегија избјегавања њиховог понављања и едукацију здравствених радникан. ${ }^{32}$

Закључак сличног истаживања спроведеног у Великој Британији такође је алармантан. Аутори истраживања дошли су до закључка да је у протеклих тридесетак година број поднијетих пријава против љекара због стручне грешке увећан око хиљаду пута. Од 2009. године у Енглеској је такође у употреби систем NHSE (National Health Service Complaints England). ${ }^{33}$

Међу водећим разлозима настанка стручне грешке у области здравства у свим спроведеним истраживањима те врсте најчешће се наводи неадекватно вођена медицинска документација. ${ }^{34}$

Медицинска документација - Медицинска документација, сходно одредбама Правилника о вођењу медицинске документације, начину уписивања података и састављања извјештаја ${ }^{35}$ и Закона о здравственој документацији и евиденцијама у области здравства, ${ }^{36}$

30 Ibid.

31 М. Почуча, Н. Шаркић, Н. Мрвић Петровић, 207.

32 Чедомир Вучетић et al., „Правни аспекти лекарске грешке“, Acta chirurgica iugoslavica 1/2011, Београд, 111.

33 Emily Jackson, Medical Law: Text, Cases and Materials, Oxford 2009, 121.

34 Сходно одредбама 333 РС и 333 ЦГ сви учесници у пружању здравствене заштите дужни су да воде одговарајућу медицинску документацију, извјештаје и евиденције.

35 Правилник о вођењу медицинске документације, начину уписивања података и састављања извјештаја, Службени гласник $P C$, бр. 40/81.

36 Закон о здравственој документацији и евиденцијама у области здравства, Службени гласник РС, бр. 123/2014. 
представља извјештај о здравственом стању лица у који се у складу са законом евидентирају све информације о медицинским мјерама које су предузете, а посебно анамнеза, дијагноза, дијагностичке мјере, терапија и резултати терапије, као и дати савјети. Љекар и други здравствени радници и сарадници имају обавезу да воде прецизну медицинску документацију у коју пацијент има право увида. Обавеза вођења медицинске документације има јавноправни карактер па би стога свако неадекватно вођење медицинске документације морало да повлачи и одређену санкцију. Због мањкавости медицинске документације могуће је наступање разних облика штете, али се све оне у најгрубљем дијеле у двије групе: штета због немогућности да се докаже начињена љекарска грешка и штета због љекарске грешке коју је условила мањкава документација. ${ }^{37}$

Иако је основна сврха и смисао вођења медицинске документације омогућавање правилног лијечења пацијента, она има и изузетну доказну вриједност пред судом и другим државним органима па у том смислу уредно вођење медицинске документације има вишеструк значај. Уредна медицинска документација помаже пацијенту да остварује своја права и доказује одговорност љекара за стручну грешку, док, с друге стране, љекару обезбјеђује доказ да се у раду придржавао важећих медицинских стандарда и протокола лијечења.

У случају наступања смрти пацијента, љекар је дужан да о томе одмах информише надлежне органе, да предложи вршење судскомедицинске обдукције и да такав свој поступак забиљежи у медицинску документацију, чиме обезбјеђује трајан доказ о свом исправном поступању. ${ }^{38}$ Због значаја утврђивања узорка смрти у смислу постојања кривичног дјела, прецизирано је шта мора садржати налаз и мишљење вјештака дато након извршене судскомедицинске обдукције, при чему се посебно захтијева изјашњавање о непосредном узроку смрти, шта је тај узрок изазвало, времену наступања смрти и да ли је до тога дошло због личног својства, нарочитог стања организма, случајних околности или околности под којима је нанијета повреда и да ли је благовремено пружена помоћ могла спријечити смртни исход. ${ }^{39}$ Сходно одредбама чл. 125, ст. 2 Законика о кривичном поступку $\mathrm{PC}^{40}$ и чл. 148 , ст. 2 Законика о кривичном

37 Јаков Радишић, „Медицинска документација и њен правни значај“, Право - теорија и пракса, Београд 2006, 55.

38 С. Савић, 65.

39 Наташа Мрвић Петровић, Јован Ћирић, Милан Почуча, „Медицинска вештачења у кривичном и парничном поступку, Војносанитетски преглед 8/2015, Београд, 731.

40 Законик о кривичном поступку, Службени гласник РС, бр. 72/11, 101/11, $121 / 12,32 / 13,45 / 13$ и $55 / 14$. 
поступку ЦГ $\Gamma^{41}$, за вјештака се не може одредити доктор медицине који је лијечио умрлог. Из схватљивих разлога, љекар који је лијечио преминулог изузет је од могућности да буде вјештак за преглед и обдукцију леша. Иако вјештачење увијек треба да врши љекар судскомедицинске специјализације и мало је вјероватно да је љекар те врсте специјализације претходно био у функцији лијечења умрлог, ипак то не мора бити искључено, па се на томе и темељи дио ratio legis-a одредбе која таквог љекара апсолутно искључује као вјештака за преглед и обдукцију леша. ${ }^{42}$

Дакле, као што смо претходно истакли, поступање у складу са правилима науке и струке, строго поштовање протокола лијечења и уредно вођена медицинска документација једнако су важни за пацијента као и за здравственог радника.

Нежељено дејство лијека - У контексту анализираног кривичног дјела треба истаћи да се од љекара очекује да просјечно савјесно поступа на нивоу знања просјечно едукованог љекара који прати савремена достигнућа своје струке. Разматрајући ту проблематику, треба имати на уму да лијечење и примјену лијека, односно медицинског средства у ту сврху у пракси може пратити и појава компликација које настају из различитих разлога, као што су године пацијента, природа и фаза болести, фактори ризика, друге болести од којих пацијент болује или је боловао, природа и тежина повреде, коморбидитет, биолошки одговор организма које се некритички повезују са неадекватним радом љекара. ${ }^{43}$ Такође, као важно у контексту разматране тематике, а сходно одредбама Закона о лијековима, треба истаћи да употреба лијека, ${ }^{44}$ иако у предвиђеној дози и на предвиђен начин, увијек собом носи ризик од наступања „нежељеног дејства лијека“, али и „озбиљног нежељеног дејства лијека“, који се може одразити на здравствено стање и живот пацијента. Такође, Закон о лијековима, осим тих категорија нежељеног дејства лијека, посебно дефинише и појам „неочекиваног нежељеног дејства лијека“ који представља свако штетно нежељено дејство које као такво није описано и самим тим није наведено у сажетку основних карактеристика одређеног лијека (чл. 5). ${ }^{45}$ Појам несрећног случаја у медицини подразумијева

41 Законик о кривичном поступку, Службени лист ЦГ, бр. 57/09, 49/10, 47/14, $2 / 15,35 / 15$ и $58 / 15$.

42 Милан Шкулић, Коментар Законика о кривичном поступку, Подгорица 2009, 465 .

43 С. Савић, 54.

44 Интересантно је да се крв и компоненте крви намијењене трансфузији не сматрају лијеком, међутим лијековима из крви и крвне плазме у смислу овог закона сматрају се лијекови произведени из крви и крвне плазме хуманог или животињског поријекла.

45 Закон о лијековима, Службени лист ЦГ, бр. 80/04. 
оне случајеве у којима су неповољне посљедице у току пружања здравствене заштите и помоћи наступиле услијед неких околности које се нису могле предвидјети, при чему је љекар примијенио све неопходне мјере предвиђене савременом медицинском науком и праксом да спријечи наступање тих посљедица и њихово штетно дејство на здравље пацијента односно штетне последице „наступиле су неочекивано и нису слиједиле из уобичајеног тока догађаја“, при чему фактори који доводе до таквог случаја у медицини могу бити објективног карактера (посебно неке околности случаја - нестанак струје, квар на апарату) или потицати од пацијента (лична својства или нарочито тешка стања организма). ${ }^{46}$ У том смислу, значајно је разликовати узроке погоршања здравственог стања лица по основу начињене стручне љекарске грешке и несрећног случаја у медицини будући да несрећни случај у медицини не повлачи одговорност љекара јер не представља израз његовог несавјесног поступања. У контексту анализиране проблематике чини се важним истаћи и да су у пракси чести случајеви да пацијент допринесе погоршању властитог здравља произвољним коришћењем медикамената, избјегавањем терапије или непоштовањем љекарских забрана, чак и у случајевима када су укључени у процес лијечења. ${ }^{47}$

\section{4. ОДРЕЪИВАҢЕ ПОЈМА НЕСАВЈЕСНОГ ВРШЕЊА ЗДРАВСТВЕНЕ ДЈЕЛАТНОСТИ КАО БИТНОГ ЕЛЕМЕНТА КРИВИЧНОГ ДЈЕЛА}

Појам стручне грешке у анализираном контексту традиционално се и веома упорно везује само за поступке љекара, а не и других здравствених радника, што представља веома интересанто питање. ${ }^{48}$ Управо у контексту поменуте разлике по питању учиниоца кривичног дјела несавјесног пружања љекарске помоћи, сматрамо да би то кривично дјело требало да носи назив несавјесно вршење здравствене дјелатности, чему у прилог иду и важеће одредбе Закона о здравственој заштити Србије и Закона о здравственој заштити ЦГ. Тако се, сходно одредбама Закона о здравственој заштити РС, здравственим радницима сматрају лица која су завршила медицински, стоматолошки или фармацеутски факултет и лица са завршеном другом школом здравствене струке, која непосредно као професију обављају здравствену дјелатност у здравственим установама или приватној пракси под законом прописаним условима. Осим категорије здравствених радника, закон познаје и категорију здравствених сарадни-

\footnotetext{
46 С. Савић, 55.

47 М. Почуча, Н. Шаркић, Н. Мрвић Петровић, 208.

48

Ibid.
} 
ка коју чине лица са завршеном средњом, вишом, односно високом стручном спремом која обављају одређене послове здравствене заштите у здравственој установи, односно приватној пракси. За вршење здравствене дјелатности здравствени радници и здравствени сарадници морају за одређене послове имати и одговарајућу специјализацију, односно ужу специјализацију (чл. 165, 166). И сходно одредбама Закона о здравственој заштити ЦГ, здравствену дјелатност такође врше двије категорије лица, здравствени радници и здравствени сарадници. Здравствени сарадници могу обављати здравствену дјелатност у области јавног здравства, здравствене заштите дјеце, дијагностике, заштите менталног здравља, заштите репродуктивног здравља и одраслих лица са инвалидитетом. Лицу које се у смислу тог закона не сматра здравственим радником или здравственим сарадником, забрањено је обављање здравствене дјелатности (чл. 87-89).

У смислу наведеног, а сходно категоријама које познају поменути закони, треба измијенити назив кривичног дјела несавјесно пружање љекарске помоћи у кривично дјело несавјесно вршење здравствене дјелатности и допунити одредбе КЗ у погледу учиниоца тог кривичног дјела, сходно чему, осим категорије здравствених радника која обухвата љекаре и друге здравствене раднике, то кривично дјело може учинити и здравствени сарадник.

У прилог ставу да је неопходно мијењати назив тог кривичног дјела у кривично дјело несавјесно вршење здравствене дјелатности чини се важним још једном истаћи да се појам лијечења ипак не може сувише екстензивно тумачити, па је у том контексту спорно питање на који начин третирати случајеве који немају за циљ лијечење, али захтијевају вршење здравствене дјелатности, односно подразумијевају пружање здравствене услуге која са собом носи извјестан ризик, попут све масовнијих захвата у естетској хирургији, али и бројни други случајеви у којима се здравствене услуге све чешће пружају здравим лицима. У складу са тим ставом су и одредбе Закона о здравственој заштити, сходно којима је здравствена дјелатност она дјелатност којом се обезбјеђује здравствена заштита грађана, која обухвата спровођење мјера и активности здравствене заштите које се, у складу са здравственом доктрином и уз употребу здравствених технологија, користе и за очување и за унапређење здравља људи, а коју обавља здравствена служба коју чине здравствене установе и други облици здравствене службе, односно приватна пракса, који се оснивају ради спровођења и обезбјеђивања здравствене заштите, као и здравствени радници, односно здравствени сарадници, који обављају здравствену дјелатност у складу са законом (чл. 5, 6). У том смислу, све мјере и активности здравствене заштите морају бити засноване на научним доказима, односно морају бити 
безбједне, сигурне и ефикасне и у складу са начелима професионалне етике.

Све то је у складу и са начелом законитости, као једним од најзначајнијих достигнућа кривичног права и принципа правне државе. У контексту поменуте проблематике посебно се истиче један од важних захтјева начела законитости да кривични закон мора имати висок степен одређености у погледу предвиђених инкриминација те у том смислу наведене норме морају бити прецизне у највећој могућој мјери, што се посебно односи на оне норме којима се креирају конкретне инкриминације и прописују казне за њих па сходно томе што је прецизност и одређеност кривичноправних норми већа, то је мања могућност за потенцијална и, по правилу, веома опасна тумачења таквих норми у пракси. ${ }^{49}$ Одређеност закона подразумијева и његов начелни општи карактер, што би морала бити логична консеквенца не само у начелном смислу легитимности кривичног законодавства, које подразумијева да се њиме као својеврсним ultima ratio механизмом, а то је могуће само када таква заштита има опште усмјерење, тако и у правнотехничком смислу будући да се норме кривичног права креирају за будућност, а њих тек потом суд примјењује на конкретан догађај. ${ }^{50}$

\section{5. ЗАКЉУЧНА РАЗМАТРАЬА}

Као што је у раду истакнуто, несавјесно поступање здравственог радника не мора увијек водити и погоршању здравственог стања пацијента. Стога, уколико здравствени радник очигледно несавјесно поступа, али тиме не узрокује погоршање здравственог стања лица, неће бити испуњени елементи бића кривичног дјела несавјесно пружање љекарске помоћи, али непостојање елемената бића конкретног кривичног дјела не значи да за несавјесно поступање здравствени радник не треба да сноси одређену професионалну одговорност. Као што је назначено, кривичним правом, као посљедњим средством, штити се здравље човјека од најтежих облика његовог угрожавања док се осталим гранама права рјешавају бројна питања из области остваривања права на здравље и здравствену заштиту.

Осим у раду посебно наглашених спорних питања која се односе на сувише екстензивно тумачење појма лијечења у кривичном праву па, у том контексту, и спорног назива анализираног кривичног дјела, отворено је и значајно питање категорија лица која могу бити учиниоци тог кривичног дјела. У том смислу сматрамо

49 Милан Шкулић, „Начело законитости у кривичном праву“, Анали ПФБ 1/2010, 72 .

50 Ibid., 81. 
да је, с обзиром на значајно увећање броја услуга које се све чешће пружају у области здравства а које се не могу сматрати лијечењем, неопходно мијењати назив кривичног дјела несавјесно пружање љекарске помоћи у кривично дјело несавјесно вршење здравствене дјелатности. Такође, сматрамо да би, сходно одредбама Закона о здравственој заштити РС и Закона о здравственој заштити ЦГ које познају двије категорије лица која могу обављати послове из области здравствене заштите, требало допунити одредбе КЗ у погледу тог кривичног дјела тако да се, осим категорије здравствених радника, која обухвата љекаре, односно лица са завршеним медицинским, стоматолошким или фармацеутским факултетом, и друге здравствене раднике, уведе и категорија здравствених сарадника као лица која могу учинити то кривично дјело.

На овом мјесту чини се важним указати и на значај Протокола о лијечењу, у складу са којима се, по угледу на бројне водеће земље свијета, спроводе поступци лијечења. У том смислу строго поштовање Протокола о лијечењу и уредно вођење медицинске документације истовремено би служили као критеријуми контроле рада здравствених радника и здравствених сарадника, али истовремено представљали и изузетно важне доказе приликом утврђивања њихове одговорности. Заправо, поштовање Протокола о лијечењу и прецизно вођење медицинске документације мора бити схваћено као најсигурнији вид заштите сваког здравствених радника, односно сарадника, као и лица која остварују права на здравствену заштиту.

Случајеви у којима у пракси долази до настанка стручне љекарске грешке по правилу су веома бројни. ${ }^{51}$ Упркос томе, у Сpбији, као ни у Црној Гори, не постоји евиденција о тој проблематици. Ипак, поједина осигуравајућа друштва на овим просторима нуде и ову врсту осигурања, али да би се на адекватан начин могло говорити о његовом „успјеху“, оно мора бити одређено као обавезно, као што је то учињено у Словенији. ${ }^{52}$ У контексту разматране тема-

51 У том смислу интересантан је податак да се, с обзиром на специфичност професије, често дешава да у току хируршке интервенције у тијелу пацијента буде заборављен неки од инструмената или других материјала употребљаваних у току интервенције. Хируршке грешке могу бити веома упадљиве, као што су погрешан пацијент (идентитет), погрешна страна тијела, погрешно мјесто и погрешна процедура, али се као разлози настанка стручне љекарске грешке јављују и опрема, односно техника, лијекови, комуникација и сл. У том смислу опрема може бити неисправна, комуникација нејасна, непотпуна, погрешно схваћена (нечитак рукопис) и често је то примарна грешка за настанак других грешака. Веома је важно указати на то да се разматрање поменутих медицинских грешака односи само на најеклатантније примјере начињених стручних љекарских грешака, што је заправо алармантан показатељ присуства изразито крупних грешака у послу који по замисли не прихвата грешку као допустиву. Наведено према: Ч. Вучетић, et al., 111.

52 Владимир Чоловић, „Осигурање од професионалне одговорности“, Страни правни живот 3/2010, 33. 
тике, као и значаја вођења евиденције стручних грешака у области здравства, а све са циљем њиховог откривања, праћења и отклањања узрока њиховог настанка, сматрамо да је основан у теорији све заступљенији став да је неопходно оснивање националних система за пријављивање и праћење стручних грешака у области здравствене дјелатности, попут система који су у употреби у Енглеској, Њемачкој, Француској и другим водећим земљама у области заштите права на здравље и пружање здравствене заштите.

\section{ЛИТЕРАТУРA (REFERENCES)}

Чејовић, Б., Кривично право у судској пракси, Посебни део, Крагујевац 2008. (Cejović, B., Krivično pravo u sudskoj praksi, Posebni deo, Kragujevac 2008)

Чоловић, В., „Осигурање од професионалне одговорности“, Страни правни живот 3/2010. (Ćolović, V., „Osiguranje od profesionalne odgovornosti“", Strani pravni život 3/2010)

Ђурђевић, Н., „Кривична одговорност љекара у случају самоубиства пацијента“, Југословенска ревија за криминологију и кривично право 1-2/1997. (Đurđević, N., „Krivična odgovornost ljekara u slučaju samoubistva pacijenta“, Jugoslovenska revija za kriminologiju i krivično pravo 1-2/1997)

Jackson, E., Medical Law: Text, Cases and Materials, Oxford 2009.

Мрвић Петровић, Н., Ћирић, Ј., Почуча, М., „Медицинска вештачења у кривичном и парничном поступку“, Војносанитетски преглед 8/2015. (Mrvić Petrović, N., Ćirić, J., Počuča, M., „Medicinska veštačenja u krivičnom i parničnom postupku“, Vojnosanitetski pregled $8 / 2015$ )

Pompili, M., Ferracuti, C., „Suicide and some of its legal problems with particular reference to the shizophrenia patient", Crimen 1/2011.

Почуча, М., Шаркић, Н., Мрвић Петровић, Н., „Лекарска грешка као разлог правне одговорности лекара и здравствених установа“, Војносанитетски преглед 2/2013. (Počuča, M., Šarkić, N., Mrvić Petrović, N., „Lekarska greška kao razlog pravne odgovornosti lekara i zdravstvenih ustanova“, Vojnosanitetski pregled 2/2013)

Радишић, Ј., „Медицинска документација и њен правни значај“, Право - теорија и пракса, Београд 2006. (Radišić, J., „Medicinska dokumentacija i njen pravni značaj“, Pravo - teorija i praksa, Beograd 2006.

Радишић, Ј., „Одговорност љекара због смрти пацијента изазване нехатним нечињењем - поглед у њемачку правну теорију и 
судску праксу“, Анали Правног факултета у Београду 1/2012. (Radišić, J., „Odgovornost ljekara zbog smrti pacijenta izazvane nehatnim nečinjenjem - pogled u njemačku pravnu teoriju i sudsku praksu“, Anali Pravnog fakulteta u Beogradu 1/2012)

Савић, С., „Кривична дела у вези са обављањем лекарске делатности“, Научни часопис ургентне медицине - Хало 94 2/2010. (Savić, S., „Krivična dela u vezi sa obavljanjem lekarske delatnosti“, Naučni časopis urgentne medicine - Halo 2/2010)

Степић, Д., „Кривична одговорност лекара за несавесно пружање лекарске помоћи - упоредноправна анализа кривичних законодавстава неких земаља Југоисточне Европе“, Страни правни живот 2/2009. (Stepić, D., „Krivična odgovornost lekara za nesavesno pružanje lekarske pomoći - uporednopravna analiza krivičnih zakonodavstava nekih zemalja Jugoistočne Evrope“, Strani pravni život 2/2009)

Стојановић, 3., Коментар Кривичног законика, Београд 2012. (Stojanović, Z., Komentar Krivičnog zakonika, Beograd 2012)

Стојановић, 3., Коментар Кривичног законика, Подгорица 2010. (Stojanović, Z., Komentar Krivičnog zakonika, Podgorica 2010)

Стојановић, З., Делић, Н., Кривично право, Посебни део, Београд 2015. (Stojanović, Z., Delić, N., Krivično pravo, Posebni deo, Beo$\operatorname{grad} 2015)$

Шкулић, М., Коментар Законика о кривичном поступку, Подгорица 2009. (Škulić, M., Komentar Zakonika o krivičnom postupku, Podgorica 2009)

Шкулић, М., „Начело законитости у кривичном праву“, Анали Правног факултета у Београду 1/2010. (Škulić, M., „Načelo zakonitosti u krivičnom pravu“, Anali Pravnog fakulteta u Beogradu 1/2010)

Вучетић, Ч. et al., „Правни аспекти лекарске грешке“, Acta chirurgica iugoslavica 1/2011. (Vučetić, Č. et al., „Pravni aspekti lekarske greške“, Acta chirurgica iugoslavica 1/2011) 
Jelena Đurišić, $\mathrm{PhD}$

Assistant Lecturer

University of Donja Gorica, Faculty of Law

\section{CONTROVERSIAL ISSUES RELATED TO THE CRIMINAL OFFENSE OF UNCONSCIENTIOUS PROVISION OF MEDICAL ASSISTANCE}

\section{Summary}

The paper discusses the more issues relating to the criminal offence of unconscientious provision of medical assistance, among which the most important are follows: the first question concerns the interpretation of terms of providing medical assistance and treatment in the context of the analyzed criminal offense and according to the this the interpretation of the title of criminal offense of unconscientious provision of medical assistance while the third raises the question about category of persons who may be offender of this criminal offence.

It also highlighted the importance of respecting the protocols of the treatment and the importance of establishing national system for reporting and monitoring of professional errors in the field of health services. Strict adherence to the protocol of the treatment and orderly conduct of medical documentations is multiple significance because it represents the safest form of protection to the health workers and associates as well as the patient.

Key words: The criminal offence of unconscientious provision of medical assistance. - Causal relationship. - Health associates.

Article history: Received: 30. 6. 2016. Accepted: 28. 11. 2016 